Relations industrielles

Industrial Relations

\title{
UNION IN AMERICA A British View, by B. C. Roberts, 136 pp. Industrial Relations Section, Princeton University, Princeton 1959.
}

\section{Gérard Dion}

Volume 14, numéro 4, octobre 1959

URI : https://id.erudit.org/iderudit/1022137ar

DOI : https://doi.org/10.7202/1022137ar

Aller au sommaire du numéro

Éditeur(s)

Département des relations industrielles de l’Université Laval

ISSN

0034-379X (imprimé)

1703-8138 (numérique)

Découvrir la revue

Citer ce compte rendu

Dion, G. (1959). Compte rendu de [UNION IN AMERICA A British View, by B. C. Roberts, 136 pp. Industrial Relations Section, Princeton University, Princeton 1959.] Relations industrielles / Industrial Relations, 14(4), 617-619.

https://doi.org/10.7202/1022137ar

Tous droits réservés @ C Département des relations industrielles de l’Université Laval, 1959
Ce document est protégé par la loi sur le droit d'auteur. L'utilisation des services d'Érudit (y compris la reproduction) est assujettie à sa politique d'utilisation que vous pouvez consulter en ligne.

https://apropos.erudit.org/fr/usagers/politique-dutilisation/ 
Whether or not the clauses in the Agreement are \&fair and logical》 was not the issue before the Board. Our task was simply to consider the facts of the dispute before us, in the Light of the Agreement between the parties and the provisions of the Trades Disputes Act.

While respecting the ability and integrity of my colleagues, I am sincerely disturbed by the reasoning applied in arriving at their conclusions.

Seniority is defined in the Agreement and Service is defined in the Agreement. Rightly or wrongly, the parties themselves have agreed to separate definitions, in two distinct clauses. Furthermore, seniority is defined in terms of classifications and departments (clause 10) thus implying restrictive intentions by the parties rather than expansive interests as concluded by my colleagues.

The grievance must therefore be dismissed.

\section{RECENSIONS - BOOK REVIEWS}

UNION IN AMERICA A British View, by $\mathrm{B}$. C. Roberts, $136 \mathrm{pp}$. Industrial Relations Section, Princeton University, Princeton 1959.

Il est toujours intéressant de connaître les opinions d'un observateur étranger, surtout quand celui-ci possède une certaine compétence. Même s'il est impossible que certains aspects essentiels ne lui échappent, il voit avec des yeux neufs et il n'est pas influencé par les préjugés du milieu. Evidemment cela ne l'empêche pas de transporter les préjugés d'un autre milieu, le sien.

En tous cas l'étude du syndicalisme américain effectuée par le professeur Roberts de l'Université de Londres mérite la considération de tous ceux qui veulent analyser ce phénomène social de ce coté de l'Atlantique.

L'auteur s'est arrêté aux aspects suivants: la structure de l'organisation syndicale, la démocratie syndicale, la corruption, la négociation collective et le contrôle de l'inflation. les relations industrielles, les syndicats et la politique.

Inutile dans cet ouvrage de chercher de longs développements, avec des références aux travaux déià parus sur le sujet. $\mathrm{Ce}$ sont des observations à la suite d'un voyage que l'auteur a fait aux Etats-Unis comme professeur invité à l'Université de Princeton. Aussi y rencontrons-nous beaucoup de choses que tous ceux qui ont une connaissance du syndicalisme aux Etats-Unis savent déjà. Cependant, ce qui rend ses considérations intéressantes, ce sont les comparaisons qu'il est amené naturellement à faire avec le syndicalisme en Grand Bretagne et le système de relations industrielles qui y existe. En outre, ici et là, il se permet d'exposer ses théories concernant l'un ou l'autre aspect du syndicalisme.

Impossible de reprendre ici tout ce qu'il touche. Je crois cependant qu'il vaut la peine de noter comment il explique l'échec de la syndicalisation des collets blancs aux Etats-Unis. \&Unions will not secure their allegiance so long as they consider white-collar employees to be simply blue-collar employees with bleached shirts ». Et il va jusqu'à dire: «Although it may appear to be contrary to the concepts of egalitarianism that are cherished in America, there is some reason to believe, from their behavior, that white-collar workers on this side of the Atlantic share the outlook of their European opposite numbers. This means that it may be necessary to develop a new type of organization that is part union, part professional association $\gg$. 
$\mathrm{Au}$ sujet du développement de l'ampleur des syndicats, il remarque que le gigantisme syndical est la résultante des mêmes facteurs complexes qui ont amené le phénomène identique dans la grande entreprises. «It has been shown that the rate of growth is determined by a stochastic process rather than by conspicuous acts of policy. $\gg$ Et de même que les hommes d'affaires considèrent invariablement comme critère de succès la grosseur des entreprises, ainsi les chefs ouvriers pour les grandes unités syndicales. Cependant l'histoire nous prouve que la taille des unions n'est pas à elle seule une garantie de leur viabilité. Et il en conclut avec cette vérité qui est souvent oubliée: When dealing with the problems generated by \&igness 》 it is important not to fall into the trap of romanticing the advantages of « smallness $\triangleright$. What is significant in union organiation as in business is not size per se, but the appropriate scale for the function.

Le chapitre consacré à la démocratie syndicale comprend plusieurs considérations valables, mais dans l'ensennble il est plutôt faible. L'auteur, qui a déjà signalé que peu des pays du monde ont une législation aussi élaborée affectant le syndicalisme, paradoxalement n'en suggère pas moins encore une intervention plus grande de la part de l'Etat. C'est là une opinion qui rencontrera difficilement l'unanimité.

L'auteur a été frappé, et avec raison, par un phénomène particulier au syndicalisme américain, celui de la corruption. L'analyse qu'il en fait mérite d'être retenue. Elle est d'une grande lucidité. Il considère la corruption sous trois formes. La première qui consiste surtout dans des pratiques louches en faveur des amis ou de ses propres intérêts sans grands bénéfices aux travailleurs. La seconde est le nol pur et simple quel que soit le déguisement dont on le couvre. Enfin la troisième est celle qui arrive lorsque les chefs ouvriers s'entendent avec les employeurs ou leurs représentants au détriment des membres du syndicat. La grande centrale américaine mène un dur combat contre la corruption, mais elle ne possede pas de pouvoir pour la faire disparaftre complètement a cause de l'autonomie des unions afliées. La législation est aussi peu ef- ficace à cause de la division des responsabilités entre les Etats et le gouvernement fédéral. Mais le problème est bien plus fondamental que cela. Le mal n'est pas facile à éliminer, car la corruption n'existe pas seulement dans les syndicats ouvriers, elle est chez les employeurs, dans les partis politiques, dans toute la société. Ce n'est pas seulement parce que les syndicats américains sont des syndicats d'affaires * Corruption certainly has something to do with the social goals of an institution, but the behavior of union members is not conditioned by their union membership alone. It is a product of the values of the society to which they belong; a union cannot avoid being a mirror of the qualities that are accepted in that society in the round. It would, then, seem that there is no absolute reason why American unions should be faced with a problem of corruption other than the fact that corruption is a problem of American society.

Et l'auteur n'a pas des paroles douces pour qualifier les employeurs « If employers continue to offer bribes, pay <kickbacks s, and provide, through intermediaries, lavish expenditures for the purpose of corrupting and suborning union officials, the problem will not be solved. It would be unfair to tar all businessman with this brush, but it is apparent that some employers are only too eager to use criminals, to spend money without regard for the morality of what they are doing, and many make no bones about their preference for a union leader of James Hoffa's type over one like Walter Reuther.

The hatred felt towards Walter Reuther by businessmen is astohishing in its vehemence. Such bitter feeling towards a man who, by every test, is not only a union leader of absolute probity, but has an outstanding record of intelligent, responsible leadership, is in itself a sign of moral sickness. > Ce chapitre consacré à la corruption devrait faire réfléchir tous ceux qui veulent l'assainissement du symdicalisme américain. Il a touché le fond de la question.

Dans son étude sur les relations industrielles, l'auteur est frappé par l'animosité qui existe entre entreprises et 
syndicats. Les rapports sont beaucoup plus amicaux en Europe. \&What is, perhaps, most paradoxical is that industrial relations in countries with a far less egalitarian social structure than America, and in which trade unions have a strong ideological character, should be less marked by bitter antagonism. » Il s'étend longuement sur la négociation, l'arbitrage et la grève et constate que de part et d'autre on est devenu prisonnier d'un comportement qui s'est institutionnalisé. Bien que la négociation collective sur le plan de l'usine soit beaucoup plus poussée qu'en Europe, «American management appears to be far more determined to maintain its past prerogatives than management in Europe ». On se bat encore pour des pseudo-principes alors que l'on devrait travailler à trouver un modus vivendi avantageux pour tous. La démocratisation de l'industrie est encore à venir. Si la dictature industrielle a été peu à peu modifiée dans le sens de la démocratie par l'avènement des unions, les principes fondamentaux qui inspirent la direction des entreprises sont encore de type totalitaire. Ce n'est certainement pas avec un tel système que les Etats-Unis réussiront à attirer dans leur orbitre les nations d'Afrique et d'Asie qui répugnent à accepter cet aspect autoritaire du capitalisme privé.

Enfin l'auteur compare l'action politique des syndicats américains avec celle des syndicats anglais. Il se montre franchement favorable à une action politique qui sauvegarde l'autonomie de chacune de ces institutions. Il est très dangereux d'empêcher les syndicats de faire de la politique. \& The result of any such action would almost certainly be to stimulate the unions to much greater industrial militancy. What the unions would be deprived of seeking through democratic political action, they would be compelled to struggle for by other means. The possible repercussions ought to be pondered carefully before any attempt to prohibit the political activities of the unions is seriously contemplated. \$ Quand on critique les unions parce qu'elles flirtent du coté politique, on doit se souvenir qu'elles ont eu à lutter durement pour conquérir tout ce qu'elles possèdent de droits: droit d'exister, droit de négocier, droit de grève, droit de participer à l'élaboration de la législation qui affecte vitalement les intérêts économiques et sociaux de leurs membres. Dans tous les pays, les unions jouent un rôle important dans la politique. Alors il ne faudna pas se surprendre si, de plus en plus, les syndicats américains auront à abandonner leur traditionnelle attitude de neutralité, sans pourtant devenir prisonniers d'un parti.

Ainsi qu'on aura pu le constater, l'auteur a abordé tous les aspects du syndicalisme américain qui font à l'heure actuelle objet de discussions acerbes. Aussi nous souhaitons que son ouvrage soit hu par tous ceux qui se mêlent de parler du syndicalisme souvent à tort et à travers. On peut ne pas partager toutes les opinions de l'auteur, mais celles-ci valent la peine d'être soigneusement considérées.

Gérard Dion

Le coût de la Sécurité Sociale, 19491954, Bureau International du Travail, Genève, 1958, 204 pp. \$3.00.

Depuis deux décades, des systèmes de sécurité sociale sont apparus très nombreux dans la plupart des pays. Ils affectent considérablement l'économie de ces pays et il est très utile de connaître à fond les problèmes financiers des divers systèmes afin de calculer leurs effets sur l'économie nationale de chaque nation.

Le Bureau International du Travail a accompli un travail considérable et dont le besoin était urgent dans le domaine de la compilation, l'analyse et la diffusion des données sur le coût de la sécurité sociale à travers le monde. En 1952 et en 1955 le B.I.T. publiait ses deux premières études à ce sujet.

L'étude publiée en 1958 répondait à deux préoccupations. \& Il s'agissait en premier lieu », souligne l'introduction, «de présenter, par pays, un état complet et coordonné des opérations financières des régimes de sécurité sociale considérée comme rentrant dans le champ de l'enquête. En deuxième lieu l'étude est une étape en vue d'établir une comparaison internationale de la répartition du coût de la sécurité sociale. 